The Chittagong Univ. J. B. Sci., Vol. 3(1 \&2):pp.11-20, 2008.

\title{
FACTORS RESPONSIBLE FOR PRODUCTION OF AMYLASES FROM ASPERGILLUS FUMIGATUS FRESENIUS
}

\author{
MUNIRA AKHTER, MD. TOWHID HOSSAIN AND M. N. ANWAR* \\ Department of Microbiology, University of Chittagong, Chittagong- 4331, Bangladesh.
}

\begin{abstract}
Aspergillus fumigatus Fresenius showed maximum amylase production at $27^{\circ} \mathrm{C}$ with an initial culture $\mathrm{pH}$ of the medium 6.0 after $72 \mathrm{~h}$. of incubation. One per cent soluble starch and $0.15 \%$ ammonium nitrate in the medium supported the highest amylase activity. During enzyme-substrate reaction maximum enzyme activity was observed at $50^{\circ} \mathrm{C}$ and $\mathrm{pH} 4.0$ with $2 \%$ starch.
\end{abstract}

Key words: Factors, Amylases, Aspergillus fumigatus

\section{INTRODUCTION}

Amylases represent a group of enzymes of great importance to the food industry and other needs of life. They were also one of the first to be produced industrially by microorganisms (Reed 1975). Amylases have most widely been reported to occur in microorganisms, although they are also found in plants and animals. Two major classes of amylases have been identified in microorganisms, namely $\alpha$-amylase and glucoamylase. They have immense potential for commercial production. In addition, $\beta$-amylase, which is generally of plant origin, has also been reported from a few microbial sources (Pandey et al. 2000). Since starch is the only natural substrate to be hydrolyzed by amylases, it is desirable to recover potential microbial isolates producing high level of amylase active on raw starch (Pandey et al. 2000). Fungal amylase activity is influenced to a great extent by pH (Abu-Zeid 1997, Filipov et al. 1982, Kachelkina and Oreshchenko 1980, Okolo et al. 1995, Olasupo et al. 1996, Rahman et al.1993), temperature (Abu-Zeid 1997, Okolo et al. 1995, Olasupo et al. 1996, Srivastava and Baruah 1986), incubation period (Bormiss et al. 1981, Marzan et al. 2001, Rahman et al.1993), various carbon and nitrogen sources (Guo et al. 1988, Lachmund and Ruttkowski 1990,Mahmoud 1993, Okolo et al. 1995) and also substrate concentration. Considering the above, the present work has been under taken to investigate the influence of some factors on the production and activity of amylases from the fungal isolate Aspergillus fumigatus.

\footnotetext{
* Corresponding author.
} 
MUNIRA AKHTER ET AL.

\section{MATERIALS AND METHODS}

Organism

Aspergillus fumigatus Fresenicus was obtained from the Department of Microbiology, University of Chittagong, Bangladesh.

\section{Culture Medium}

Aspergillus fumigatus was cultured in defined salt medium (Almieda et al. 1997) containing $0.5 \% \quad \mathrm{KH}_{2} \mathrm{PO}_{4}, 0.67 \% \quad \mathrm{~K}_{2} \mathrm{HPO}_{4}, \quad 0.1 \% \quad\left(\mathrm{NH}_{4}\right)_{2} \mathrm{SO}_{4}, 0.01 \%$ $\mathrm{MgSO}_{4} .7 \mathrm{H}_{2} \mathrm{O}$ and $4 \%$ soluble starch.

Assay of Enzyme Activity

Assay system for amylase activity was carried out by measuring the amount of reducing sugar following Nelson's modification of Somogyi method (Nelson 1944). The reaction mixture contained $5 \mathrm{ml}$ of $1 \%$ soluble starch prepared in $0.2 \mathrm{M}$ citrate phosphate buffer $(\mathrm{pH} \mathrm{6.0),} 1 \mathrm{ml}$ of $0.2 \mathrm{M}$ citrate phosphate buffer and $1 \mathrm{ml}$ of enzyme solution. The reaction mixture was incubated at $37^{\circ} \mathrm{C}$ for $1 \mathrm{~h}$. Then $1 \mathrm{ml}$ of alkaline copper reagent was added to $1 \mathrm{ml}$ of reaction mixture, and the mixture was boiled for $20 \mathrm{~min}$, cooled and $1 \mathrm{ml}$ of arsenomolybdate colour reagent was added. After $10 \mathrm{~min}$ the reaction mixture was diluted with $22 \mathrm{ml}$ of distilled water and the absorbance was measured at 550 $\mathrm{nm}$. Enzyme activity was expressed as the amount of glucose released per $\mathrm{ml}$ of enzyme extract per unit time (Mohadevan and Sridhar 1982). [One unit (U) enzyme activity is the amount of enzyme required to release $1 \mu \mathrm{mol}$ glucose equivalent in 1 min under the assay condition].

\section{Protein Estimation}

Protein was determined by the method of Lowry et al. (1951).

\section{Biomass yield}

Biomass was determined by dry weight basis (mg/g substrate).

\section{Saccharification}

For saccharification the enzyme preparation (crude) was adjusted to $\mathrm{pH}$ 4.0 and sodium azide $(0.2 \%)$ was added to inhibit the microbial growth. Hydrolysis was carried out under stationary condition in $25 \mathrm{ml}$ screw cap test tubes at $50^{\circ} \mathrm{C}$ with substrate (starch) concentration of $7.5 \%(\mathrm{w} / \mathrm{v})$ for $24 \mathrm{~h}$. and 48 h. of intervals (Begum et al. 1993). The sugar content in the hydrolysate was measured by Nelson's modification of Somogyi method (Nelson 1944).

Per cent of saccharification was calculated as follows:

$$
\text { Saccharification } \%=\frac{\mathrm{mg} \text { of reducing sugar } / \mathrm{ml}}{\mathrm{mg} \text { of substrate } / \mathrm{ml}} \times 100
$$


PRODUCTION OF AMYLASES FROM ASPERGILLUS FUMIGATUS

\section{Effect of Culture Conditions on Amylase Production}

The fungal isolate was grown at various $\mathrm{pH}(4,5,6,7,8$ and 8.5) and temperature $\left(10^{\circ} \mathrm{C}, 27^{\circ} \mathrm{C}, 37^{\circ} \mathrm{C}\right.$ and $\left.45^{\circ} \mathrm{C}\right)$ for various incubation periods $(48,72$, 96, 120 and 144 h.) using different nitrogen sources $\left(\mathrm{NH}_{4} \mathrm{NO}_{3}, \mathrm{NH}_{4} \mathrm{Cl}\right.$, $\left(\mathrm{NH}_{4}\right)_{2} \mathrm{HPO}_{4}$, glutamine, glycine and peptone) for the optimization of growth conditions and to investigate the effects of these factors on amylase production. To determine optimum percent of carbon and nitrogen sources, the study was also carried out with 1 to $5 \%$ carbon and 0.05 to $0.30 \%$ nitrogen sources keeping other experimental conditions at optimum.

\section{Effect of Incubation Time on Amylase Activity}

To determine the effect of incubation time on enzyme activity the enzyme substrate mixture was incubated at different incubation time $(15,30,45,60,75$ and $90 \mathrm{~min}$ ).

\section{Effect of $\mathrm{pH}$ and Temperature on Amylase Activity}

The effect of $\mathrm{pH}$ on amylase activity was determined by incubating the reaction mixture at $\mathrm{pH} 3.0$ to 8.0 using citrate phosphate buffer (adjusted with $1 \%$ $\mathrm{Na}_{2} \mathrm{HPO}_{4} .7 \mathrm{H} 2 \mathrm{O}$ solution). The optimum temperature for enzyme activity was also determined by assaying the enzyme activity at various temperatures from 35 to $55^{\circ} \mathrm{C}$.

\section{RESULTS AND DISCUSSION}

\section{Effect of incubation period on amylase production}

When the fungus was incubated at different incubation period the isolate was found to produce maximum amylase at $72 \mathrm{~h}$. of incubation period (Table 1). Though $72 \mathrm{~h}$. of incubation showed the highest amylase activity but the highest biomass yield was recorded at $96 \mathrm{~h}$. of incubation period. The colour of the supernatant was sand gold. The $\mathrm{pH}$ of the supernatant ranged from 5.02 to 6.72 . The maximum protein and the saccharification rate were recorded at 96 and 120 h. of incubation period, respectively. Production of maximum amylase after $72 \mathrm{~h}$. of incubation period by fungi was reported by many workers (Cherry et al. 2004, Gargova and Nauchni 1979, Mahmud 2006, Rahman et al. 1993). 
MUNIRA AKHTER ET AL.

TABLE 1: EFFECTS OF INCUBATION PERIOD ON PRODUCTION OF AMYLASES BY A. FUMIGATUS.

\begin{tabular}{clcccc}
\hline $\begin{array}{c}\text { Incubation } \\
\text { Period } \\
(\text { In hrs })\end{array}$ & $\begin{array}{l}\text { Biomass } \\
\text { yield } \\
(\mathrm{mg} / \mathrm{g})\end{array}$ & $\begin{array}{c}\text { Reducing } \\
\text { sugar } \\
(\mu \mathrm{g} / \mathrm{ml})\end{array}$ & $\begin{array}{c}\text { Protein } \\
(\mu \mathrm{g} / \mathrm{ml})\end{array}$ & $\begin{array}{c}\text { Saccharification } \\
\%\end{array}$ & $\begin{array}{c}\text { Amylase } \\
\text { activity } \\
(\mathrm{U} / \mathrm{ml})\end{array}$ \\
\hline 48 & 290 & 307 & 243 & 0.76 & 370 \\
72 & 439 & 333 & 490 & 0.83 & $378^{*}$ \\
96 & $525^{*}$ & 370 & $611^{*}$ & 0.92 & 365 \\
120 & 375 & $489 *$ & 557 & $1.22^{*}$ & 287 \\
144 & 323 & 478 & 522 & 1.19 & 295 \\
\hline
\end{tabular}

*Maximum yield

Effect of temperature and $\mathrm{pH}$ on amylase production

The effect of $\mathrm{pH}$ and temperature on the enzyme production was conducted. The optimal temperature for enzyme production was found at $27^{\circ} \mathrm{C}$ (Table 2). The highest protein, reducing sugar production and saccharification rate were recorded at $37^{\circ} \mathrm{C}$. The $\mathrm{pH}$ of the culture filtrates varied from 5.97 to 6.55 . Similar observation was made by many researchers (Fabiana et al. 1999, Mahmud 2006, Rahman et al. 1993).

TABLE 2: EFFECTS OF INCUBATION TEMPERATURE ON PRODUCTION OF AMYLASES BY A. FUMIGATUS.

\begin{tabular}{lccccc}
\hline $\begin{array}{l}\text { Incubation } \\
\text { temperature } \\
\left({ }^{\circ} \mathrm{C}\right)\end{array}$ & $\begin{array}{c}\text { Biomass } \\
\text { yield } \\
(\mathrm{mg} / \mathrm{g})\end{array}$ & $\begin{array}{c}\text { Reducing } \\
\text { sugar } \\
(\mu \mathrm{g} / \mathrm{ml})\end{array}$ & $\begin{array}{c}\text { Protein } \\
(\mu \mathrm{g} / \mathrm{ml})\end{array}$ & $\begin{array}{c}\text { Saccharification } \\
\%\end{array}$ & $\begin{array}{c}\text { Amylase } \\
\text { activity } \\
(\mathrm{U} / \mathrm{ml})\end{array}$ \\
\hline 10 & 00 & 306 & 290 & 0.76 & 239 \\
27 & 211 & 430 & 738 & 1.07 & $370^{*}$ \\
37 & $414^{*}$ & $466^{*}$ & $788^{*}$ & $1.16^{*}$ & 353 \\
45 & 343 & 401 & 753 & 1.00 & 264 \\
\hline
\end{tabular}

The optimum $\mathrm{pH}$ for enzyme production was 6.0 (Table 3). Maximum protein formation, biomass yield and saccharification rate were recorded at $\mathrm{pH}$ 8.0, 7.0 and 6.0, respectively. The results are in agreement with the findings of other investigators who observed maximum enzyme activity, protein and biomass formations at $\mathrm{pH} 6.0$ by Aspergillus spp. (Abu et al. 2005, Abu-Zeid 1997, Fabiana et al. 1999, Okolo et al.1995) and other fungi (Mahmoud 1993) and bacteria (Freer 1993). 
PRODUCTION OF AMYLASES FROM ASPERGILLUS FUMIGATUS

TABLE 3: EFFECTS OF pH OF MEDIUM ON PRODUCTION OF AMYLASES BY $A$. FUMIGATUS.

\begin{tabular}{cccccc}
\hline $\begin{array}{c}\text { Medium } \\
\mathrm{pH}\end{array}$ & $\begin{array}{c}\text { Biomass } \\
\text { yield } \\
(\mathrm{mg} / \mathrm{ml})\end{array}$ & $\begin{array}{c}\text { Reducing } \\
\text { sugar } \\
(\mu \mathrm{g} / \mathrm{ml})\end{array}$ & $\begin{array}{c}\text { Protein } \\
(\mu \mathrm{g} / \mathrm{ml})\end{array}$ & $\begin{array}{c}\text { Saccharification } \\
\%\end{array}$ & $\begin{array}{c}\text { Amylase } \\
\text { activity } \\
(\mathrm{U} / \mathrm{ml})\end{array}$ \\
\hline 4.0 & 231 & 341 & 570 & 0.85 & 337 \\
5.0 & 308 & 338 & 720 & 0.84 & 350 \\
6.0 & 434 & $399^{*}$ & 770 & $0.99^{*}$ & $481^{*}$ \\
7.0 & $529^{*}$ & 354 & 529 & 0.88 & 338 \\
8.0 & 280 & 368 & $771^{*}$ & 0.92 & 334 \\
8.5 & 240 & 385 & 760 & 0.96 & 326 \\
\hline
\end{tabular}

Effect of nitrogen sources on amylase production

In the present study the fungal isolate exhibited the highest amylases formation and biomass yield in $\mathrm{NH}_{4} \mathrm{NO}_{3}$ containing medium (Table 4). The highest reducing sugar and saccharification rate were recorded with $\left(\mathrm{NH}_{4}\right)_{2} \mathrm{HPO}_{4}$. The culture filtrate exhibited highest level of soluble protein when grown in the medium containing $\mathrm{NH}_{4} \mathrm{Cl}$ as nitrogen source. Effects of organic and inorganic nitrogen sources on amylase production have been reported by other workers (Cherry et al. 2004, Lachmund and Ruttkowski 1990, Mahmoud 1993, Tryavsogolova et al. 1986, Xiangzhang et al. 1988). It was also reported that amylase production was induced by inorganic nitrogen (Hizukuri and Susumu 1983).

TABLE 4: EFFECTS OF DIFFERENT NITROGEN SOURCES ON PRODUCTION OF AMYLASES BY A. FUMIGATUS.

\begin{tabular}{lccccc}
\hline $\begin{array}{l}\text { Nitrogen } \\
\text { sources }\end{array}$ & $\begin{array}{c}\text { Biomass } \\
\text { Yield } \\
(\mathrm{mg} / \mathrm{g})\end{array}$ & $\begin{array}{c}\text { Reducing } \\
\text { sugar } \\
(\mu \mathrm{g} / \mathrm{ml})\end{array}$ & $\begin{array}{c}\text { Protein } \\
(\mu \mathrm{g} / \mathrm{ml})\end{array}$ & $\begin{array}{c}\text { Saccharification } \\
\%\end{array}$ & $\begin{array}{c}\text { Amylase } \\
\text { activity } \\
(\mathrm{U} / \mathrm{ml})\end{array}$ \\
\hline $\mathrm{NH}_{4} \mathrm{NO}_{3}$ & $248^{*}$ & 400 & 520 & 1.00 & $405^{*}$ \\
$\mathrm{NH}_{4} \mathrm{Cl}$ & 162 & 377 & $721^{*}$ & 0.94 & 349 \\
$\left(\mathrm{NH}_{4}\right)_{2} \mathrm{HPO}_{4}$ & 81 & $406^{*}$ & 370 & $1.01^{*}$ & 381 \\
$\mathrm{Glycine}_{\text {Glutamine }}$ & 224 & 384 & 529 & 0.96 & 357 \\
Peptone & 127 & 346 & 671 & 0.86 & 364 \\
\hline
\end{tabular}

Effect of starch and nitrogen concentrations on amylase production

The effect of starch (1-5\%) and $\mathrm{NH}_{4} \mathrm{NO}_{3}(0.05-0.30 \%)$ concentrations was studied under otherwise identical culture conditions and the results are 
MUNIRA AKHTER ET AL.

summarized in Table 5. Maximum biomass and protein yields were recorded with $5 \%$ starch and $0.30 \% \quad \mathrm{NH}_{4} \mathrm{NO}_{3}$. The table 6 shows the maximum amylase production that recorded in the culture supernatant with $1 \%$ starch and $0.15 \%$ $\mathrm{NH}_{4} \mathrm{NO}_{3}$ in the basal medium. It was observed that the increase of the concentration of $\mathrm{NH}_{4} \mathrm{NO}_{3}$ gradually decreased the synthesis of amylase formation.

The effect of concentration of nitrogen sources on microbial amylase production has been reported by other workers (Bormiss et al. 1981, Hizukuri and Susumu 1983, Tryasogolova et al. 1986, Xianzhang et al. 1988).

TABLE 5: EFFECTS OF DIFFERENT CONCENTRATIONS OF STARCH AND NITROGEN SOURCES ON THE PRODUCTION OF REDUCING SUGAR, PROTEIN AND SACCHARIFICATION RATE (\%) BY A. FUMIGATUS.

\begin{tabular}{|c|c|c|c|c|c|c|c|c|c|c|c|c|c|c|c|}
\hline \multirow{3}{*}{$\begin{array}{c}\% \\
\mathrm{NH}_{4} \mathrm{NO}_{3} \\
\text { as nitrogen } \\
\text { source }\end{array}$} & \multicolumn{15}{|c|}{$\%$ Starch as carbon source } \\
\hline & \multicolumn{3}{|c|}{1.0} & \multicolumn{3}{|c|}{2.0} & \multicolumn{3}{|c|}{3.0} & \multicolumn{3}{|c|}{4.0} & \multicolumn{3}{|c|}{5.0} \\
\hline & A & $\mathrm{B}$ & $\mathrm{C}$ & A & $\mathrm{B}$ & $\mathrm{C}$ & A & B & $\mathrm{C}$ & A & $\mathrm{B}$ & $\mathrm{C}$ & A & $\mathrm{B}$ & $\mathrm{C}$ \\
\hline 0.05 & 330 & 478 & 3.3 & 402 & 622 & 2.01 & 337 & 594 & 1.12 & 433 & 946 & 1.08 & $451^{*}$ & 919 & 0.90 \\
\hline 0.10 & 381 & 763 & $3.81 *$ & 303 & 498 & 1.51 & 274 & 566 & 0.91 & 439 & 980 & 1.09 & 379 & 898 & 0.75 \\
\hline 0.15 & 375 & 457 & 3.75 & 279 & 572 & 1.39 & 244 & 539 & 0.81 & 233 & 991 & 0.58 & 301 & 865 & 0.60 \\
\hline 0.20 & 377 & 477 & 3.77 & 223 & 658 & 1.11 & 275 & 572 & 0.91 & 206 & 830 & 0.51 & 343 & 924 & 0.69 \\
\hline 0.25 & 330 & 436 & 3.3 & 179 & 541 & 0.89 & 271 & 460 & 0.90 & 187 & 898 & 0.46 & 278 & 992 & 0.55 \\
\hline 0.30 & 254 & 454 & 2.54 & 252 & 514 & 1.26 & 250 & 590 & 0.83 & 240 & 867 & 0.60 & 336 & $997^{*}$ & 0.67 \\
\hline
\end{tabular}

Note: $\mathrm{A}=$ Reducing sugar $(\mu \mathrm{g} / \mathrm{ml}), \mathrm{B}=$ Protein $(\mu \mathrm{g} / \mathrm{ml}), \mathrm{C}=$ Saccharification rate $(\%)$.

*Maximum yield.

TABLE 6: EFFECT OF DIFFERENT CONCENTRATIONS OF STARCH AND NITROGEN SOURCES ON PRODUCTION OF AMYLASE BY A. FUMIGATUS.

\begin{tabular}{|c|c|c|c|c|c|}
\hline \multirow{3}{*}{\begin{tabular}{l}
\multicolumn{1}{c}{$\%$} \\
$\mathrm{NH}_{4} \mathrm{NO}_{3}$ \\
as nitrogen \\
source
\end{tabular}} & \multicolumn{5}{|c|}{ \% Starch as carbon source } \\
\hline & 1.0 & 2.0 & 3.0 & 4.0 & 5.0 \\
\hline & \multicolumn{5}{|c|}{$\begin{array}{l}\text { Amylase activity } \\
(\mathrm{U} / \mathrm{ml})\end{array}$} \\
\hline 0.05 & 189 & 148 & 195 & 208 & 78 \\
\hline 0.10 & 179 & 177 & 156 & 76 & 159 \\
\hline 0.15 & $456^{*}$ & 174 & 227 & 229 & 223 \\
\hline 0.20 & 221 & 220 & 204 & 211 & 187 \\
\hline 0.25 & 192 & 199 & 126 & 225 & 278 \\
\hline 0.30 & 217 & 178 & 193 & 219 & 178 \\
\hline
\end{tabular}


PRODUCTION OF AMYLASES FROM ASPERGILLUS FUMIGATUS

Effect of incubation time, temperature and $\mathrm{pH}$ on amylase activity

Incubation time, temperature and $\mathrm{pH}$ are most important factors which markedly influence enzyme activity. The maximum amylase activities of Aspergillus fumigatus were recorded at $50^{\circ} \mathrm{C}$ for $30 \mathrm{~min}$ at $\mathrm{pH} 4.0$, after which the activity decreased (Fig 1)). Similar amylase activities at acidic $\mathrm{pH}$ and high temperature were reported by many workers (Akhter et al. 1999, Campos and Felix 1995, Dey et al. 2002, Glymph and Stutzenberger 1977, Teodoro and Martin 2000).

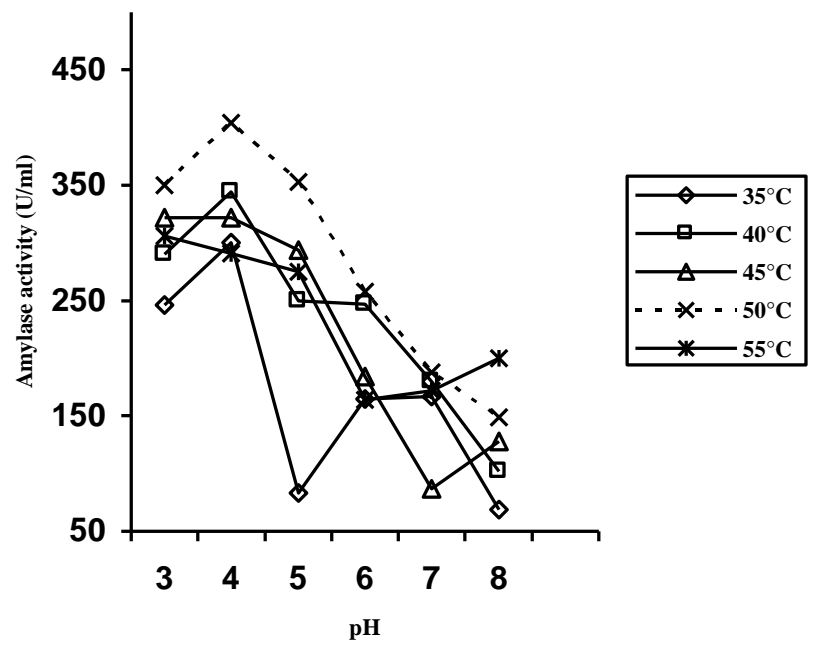

FIG 1: EFFECT OF pH AND TEMPERATURE ON AMYLASE ACTIVITY BY $A$. FUMIGATUS.

In the present observation, high temperature $\left(50^{\circ} \mathrm{C}\right)$ and low $\mathrm{pH}(4.0)$ for maximum enzyme activity indicate a good commercial probability of the amylase enzymes produced by the fungal isolate Aspergillus fumigatus.

\section{REFERENCES}

ABU, E.A., ADO, S.A. AND JAMES, D.B. 2005. Raw starch degrading amylase production by mixed culture of Aspergillus niger and Saccharomyces cerevisae grown on sorghum pomace. African J. Biotechnol. 4(8):785790. 
MUNIRA AKHTER ET AL.

ABU-ZEID, A. M. 1997. Production, purification and characterization of an extracellular alpha-amylase enzyme isolated from Aspergillus flavus. Microbios. 89(358): 55-56.

AKHTER, S., HOSSAIN, M.T., RAHMAN, M.S., MANCHUR, M.A. AND ANWAR, M.N. 1999. Isolation of amylase producing fungi and their amylase activity. The Chittagong Univ. J. Science. 23(2):107-113.

ALMEIDA, E.M. D.S., MIZUTA, K. and GIGILO, J.R. 1997. Pycnoporus sanguineus: a novel source of $\alpha$-amylase. Mycol, Res. 101(2): 188-190.

BEGUM, A. A. CHOWDHURY, N. AND SARDAR, A. H. 1993. Production of cellulose by fungal isolates in solid state fermentation and saccharification of rice bran and sugarcane bagasse. Bangladesh $J$. Microbiol. 10(1):21-27.

BORMISS, R., SCHMIDT, D., RUFTOFF, F. E., HEINZ, T. A. L., STEFFEN, P. WOLFGANY, H. AND URSULA, G. 1981. Enzyme mixture for saccharification of grain mash. Ger (East) D.D 152: 142.

CAMPOS, L. AND FELIX, C.R. 1995. Purification and Characterization of Flucoamylase from Humicola grisea. Appl. Environ. Microbiol. 61(6):2436-2438.

CHERRY, H.M., HOSSAIN, M.T. AND ANWAR, M.N. 2004. Extracellular glucoamylase from the isolate Aspergillus fumigatus. Pak. J. Biol. Sci. 7(11): 1988-1992.

DEY, G., NAGPAL, V. AND BANERJEE, R. 2002.Immobilization of alphaamylase from Bacillus circulans GRS313 on Coconut fiber. Applied. Biochemistry and Biotechnology. 103(1-3): 303-314.

FABIANA G. M., FRANCIELI A.D.L., SOPHIA R.F.P., VERIDIANA L., CRISTINA G.M D. S. AND ROSANE M. P.1999. The production of amylases by Aspergillus tamarii. Rev. Microbiol. 30(2).Sao Paulo.

FILIPOV, S.A., AVAKYANTS, S.P. AND BARTENEV, S.P. 1982. Conditions for the immobilization of cells of microscopic fungi and their use for enzymatic hydrolysis of starch. Ferment. Spirt. Prom-st. 2:30-31.

FREER S.N. 1993. Purification and characterization of the extracellular alphaamylase from Streptococcus bovis JB1. Appl. Environ. Microbiol. 59(5):1398-1402.

GARGOVA, S. AND NAUCHNI, T. 1979. Study of some condition for the biosynthesis of amylolytic enzymes by Aspergillus sp. 16/132, Vkusova prom-st. Plovdiv, 26(1): 319-330.

GLYMPH, J.L. AND STUTZENBERGER, F.J. 1977. Production, purification and characterization of alpha-amylase from Thermomonospora curvata. Appl. Environ. Microbiol. 34(4): 391-397. 
GUO, Y.,HAUNG, L., ZHAO, M., CHEN, H., PENG, X., LUO, G AND LI, L. 1988.Production of glucoamylase by immobilized cells. Conditions for batch fermentation and semicontineuous fermentation. Shipin Yu Fajiao Gongye 2: 28-31.

HIZUKURI AND SUSUMU 1983. Aspergillus strains and their use to produce Dglucose from starch. Eur. Pat. Appl. Up. 134, 546.

LACHMUND, A. AND RUTTKOWSKI, E. 1990. Investigations on the expression and regulation of the alpha-amylase gene from Aspergillus oryzae. DECHEMA Biotechnol. Conf 4:399-402.

KACHELKINA, A.I. AND ORESHCHENKO, L.I. 1980. Saparating alphaamylase from a culture medium. U.S.S.R. 668:348.

LOWRY, O.H., ROSEBROUGH, N. J., FARR, A. F., AND RANDALL, R. J. 1951. Protein Measurement with the Folin-Phenol Reagent. J. Biol. Chem. 193:265-275.

MAHADEVAN A.AND SRIDHAR R. 1982. Methods in physiological plant pathology. Siva Kami Pub. Madras. PP.316

MAHMOUD, A. L. E. 1993. Different factors affecting growth and amylase production by fungi inhabiting poultry feeds. J. Basic Microbiol. 33(3): 187-192.

MAHMUD, N. 2006. Isolation, purification and characterization of amylase from Listeria denitrificans and Aspergillus versicolor. M.S. thesis pp. 106171.

MARZAN, L.W., M.A. MANCHUR, M.T. HOSSAIN AND M.N. ANWAR 2001.Production of protease and alpha-amylase by Fusarium poae. Bangladesh J. Microbiol. 18:127-134.

NELSON, N. 1944. A Photometric adaptation of the Somogy method for the determination of glucose. J. Biol. Chem 153: 375-380.

OKOLO, B.N. EZEOGU, LEWIS M. I., AND CHARLES N. 1995. Production of raw starch digesting amylase by Aspergillus niger grown on native starch sources. J. Sci. Food Agric. 69(1): 109-115.

OLASUPO, N.A., TENIOLA, O.D., OKASUN, R., OMAWAYE, A., OLATROPE, S.O. AND SCOTT E.M.B. 1996. Studies on an amylolytic strain of Saccharomyces cerevisiae isolated from yam tuber. J. Basic Microbiol. 36: 288-293.

PANDEY, A., NIGAM, P. SOCCOL, C. R., SOCCOL, V. T. SINGH, D. AND MOHAN, R.2000. Review advances in microbial amylases. Biotechnol.Appl. Biochem. 31:135-152. 
MUNIRA AKHTER ET AL.

RAHMAN, A.K.K.M.S., M.F. RAHMAN, P.K. NATH, M.M. HOQ, AND M. HOSSAIN. 1993. Glucoamylase activity of some selected strains of $A$. niger and A. oryzae. Bangladesh J. Microbiol. 10(2): 107-110.

REED, G. 1975. Enzyme in food processing ( $2^{\text {nd }}$ edition). Academic press, New York 10005 U.S.A.

TEODORO C.E.D.S. AND MARTIN, M.L.L. 2000. Culture conditions for the production of thermostable amylase by Bacillus sp. Braz J. Microbiol. 3(1): 4.

SRIVASTAVA, R. A. K. and BARUAH, J. N., 1989. Culture condition for production of thermostable amylase by Bacillus stearothermophilus Appl. Environ. Microb. 51: 179-184.

TRYAVSOGOLOVA, T.V., KAZAKOV, A.V., BURTSEVA, E.I., DVADTSALOVA, E.A. AND USTINNIKOV, B.A. 1986.Improved fermentation conditions for producer of alpha-amylase. Ferment. Spirt. Prom-st 5:36-37.

XIANGZHANG, X., CHUANXIAN, G., WENHAIR, Q., WEIWEI, X., YUNLIN, Z., CHEN, X.Y. AND JIANWEI, R.W. 1988. Studies on the technology of production of alpha-amylase by a mutant B.S.796. Shengwn Gongeneng Xuebao. 4(2):119-126.

Manuscript received on 11.10.07; Accepted on 26.6. 08

The Chittagong University Journal of Biological Sciences, Vol. 3( 1 \& 2): pp.11-20, 2008. 